Regular article

\title{
Impact of internal recycle ratio on nitrous oxide generation from anaerobic/anoxic/oxic biological nitrogen removal process
}

\author{
Xu Yan ${ }^{\mathrm{a}}$, Yunping Han ${ }^{\mathrm{b}}$, Qilu $\mathrm{Li}^{\mathrm{a}}$, Jianhui Sun ${ }^{\mathrm{a}, *}$, Xianfa Su${ }^{\mathrm{a}}$ \\ a School of Environment, Key Laboratory for Yellow River and Huai River Water Environment and Pollution Control, Ministry of Education, Henan Key \\ Laboratory for Environmental Pollution Control, Henan Normal University, Xinxiang 453007, Henan, China \\ ${ }^{\mathrm{b}}$ Research Center for Eco-Environmental Sciences, Chinese Academy of Sciences, Beijing 100085, China
}

\section{A R T I C L E I N F O}

\section{Article history:}

Received 25 June 2015

Received in revised form 13 October 2015

Accepted 7 November 2015

Available online 18 November 2015

\section{Keywords:}

Wastewater treatment

Anaerobic-anoxic-oxic process

Biological nitrogen removal

Internal recycle ratio

Greenhouse gas

Nitrous oxide

\begin{abstract}
A B S T R A C T
To evaluate the effects of internal recycle ratio on nitrous oxide $\left(\mathrm{N}_{2} \mathrm{O}\right)$ generation, we set up three laboratory-scale anaerobic-anoxic-oxic $\left(\mathrm{A}^{2} \mathrm{O}\right)$ wastewater treatment processes, with internal recycle ratios of $100 \%, 200 \%$, and $300 \%$, respectively. Total nitrogen (TN) removal was markedly enhanced from $45.8 \%$ to $61.9 \%$, as the internal recycle ratio increased from $100 \%$ to $300 \% . \mathrm{N}_{2} \mathrm{O}$ generation was increased from 3.47 to $9.81 \times 10^{-2} \mathrm{mg} / \mathrm{L}$ during the treatment process, with the anoxic section showing the largest $\mathrm{N}_{2} \mathrm{O}$ increment from denitrification. This phenomenon is attributed to the increased amount of nitrate $\left(\mathrm{NO}_{3}{ }^{-} \mathrm{N}\right)$ substrate available for denitrification, due to the increased volume of internal recycle liquid, as well as the increased amount of oxygen, which could restrain the activity of nitrous oxide reductase brought to the anoxic section. Nitrous oxide reductase was more sensitive to oxygen than nitrate and nitrite reductases. Microorganism analysis indicated that the population of nosZ gene-containing bacteria was only slightly affected by the recycle ratio. However, the number of nosZ gene copies decreased as the internal recycle ratio increased from $100 \%$ to $300 \%$; this result reveals noticeable decreases in the denitrification capacity of the system for reducing $\mathrm{N}_{2} \mathrm{O}$ to $\mathrm{N}_{2}$.
\end{abstract}

(c) 2015 Elsevier B.V. All rights reserved.

\section{Introduction}

The contribution of greenhouse gases (GHGs) to global warming has elicited great concern from various sectors in the recent decades. Wastewater treatment plants (WWTPs) are considered artificial GHG emission resources because of nitrous oxide $\left(\mathrm{N}_{2} \mathrm{O}\right)$ emissions during the biological nitrogen removal (BNR) process. It is arrestive that $\mathrm{N}_{2} \mathrm{O}$ is about 300 times more greenhouse effective than carbon dioxide $\left(\mathrm{CO}_{2}\right)$, and its emission increased with a high rate of around $0.3 \%$ per year [ 1 ]. About $3.2 \%$ of all global anthropogenic $\mathrm{N}_{2} \mathrm{O}$ emissions originate from the BNR processes of WWTPs [2]. Considering the widespread use of BNR processes, as well as the hazards of $\mathrm{N}_{2} \mathrm{O}$, investigation of the effect of key operating parameters and sources of $\mathrm{N}_{2} \mathrm{O}$ emissions on the overall BNR process is an important undertaking.

$\mathrm{N}_{2} \mathrm{O}$ can be produced from both nitrification and denitrification in BNR processes. Nitrification refers to the stepwise autotrophic oxidation of ammonia $\left(\mathrm{NH}_{4}{ }^{+}\right)$to nitrite $\left(\mathrm{NO}_{2}{ }^{-}\right)$by ammonia-oxidizing bacteria (AOB), and then to nitrate $\left(\mathrm{NO}_{3}{ }^{-}\right)$

\footnotetext{
* Corresponding author. Fax: +86 3733325971

E-mail address: sunjh@htu.cn (J. Sun).
}

by nitrite-oxidizing bacteria (NOB). During nitrification, $\mathrm{N}_{2} \mathrm{O}$ is produced through two pathways. The first is the aerobic hydroxylamine oxidation pathway, in which $\mathrm{N}_{2} \mathrm{O}$ is produced from intermediates of biological hydroxylamine oxidation, probably related to significant imbalances in the metabolic activity of $A O B$, or by chemical decomposition of hydroxylamine and chemical oxidation with $\mathrm{NO}_{2}{ }^{-}$as an electron acceptor (chemo-denitrification). The second pathway is nitrifier denitrification, which involves reduction of $\mathrm{NO}_{2}{ }^{-}$by $\mathrm{AOB}$ in combination with ammonia, hydrogen, or pyruvate as electron donors, for example, at oxygen-limited conditions or elevated nitrite concentrations $[3,4]$.

Denitrification, on the other hand, refers to the reduction of $\mathrm{NO}_{3}{ }^{-}$to atmospheric nitrogen $\left(\mathrm{N}_{2}\right)$ by heterotrophic denitrifiers, with $\mathrm{NO}_{2}{ }^{-}$, nitric oxide (NO) and $\mathrm{N}_{2} \mathrm{O}$ as obligatory intermediates [5]. $\mathrm{N}_{2} \mathrm{O}$, a well-known intermediate emitted in this process, is released in high quantities in environments with high dissolved oxygen (DO) and $\mathrm{NO}_{2}{ }^{-}$concentrations and low $\mathrm{C} / \mathrm{N}$ water quality [3,6,7].

In present studies, the amounts of $\mathrm{N}_{2} \mathrm{O}$ emitted during wastewater treatment process are reported with high range of variation. Kampschreur et al. [2] concluded that $0.0-95.0 \%$ and $0.0-14.5 \%$ of the influent nitrogen could be removed through $\mathrm{N}_{2} \mathrm{O}$ generation during lab-scale and full-scale wastewater treatment, respectively. 
To reduce $\mathrm{N}_{2} \mathrm{O}$ emissions, in recent years, significant efforts have been made to understand the effect of various WWTP operating parameters on $\mathrm{N}_{2} \mathrm{O}$ production [8-10]. As a result, several parameters favoring $\mathrm{N}_{2} \mathrm{O}$ production have been identified: low dissolved oxygen concentration [11-13], accumulation of nitrite [3], rapidly changing (dynamic) conditions [14], a low ratio of chemical oxygen demand (COD) to N-compounds during heterotrophic denitrification $[15,16]$, sludge retention time (SRT) [17], $\mathrm{pH}$ [18], or toxic compounds [19].

The internal recycle ratio in BNR WWTPs performs an important function in the nitrogen removal process [20]. For example, increasing the internal recycle ratio from $100 \%$ to $400 \%$ decreases the nitrate concentration in the effluent and, hence, improves the nitrogen removal efficiency of the system [21]. The environmental conditions in the nitrification and denitrification sections of WWTP systems are also influenced by the internal recycle ratio. Therefore, our hypothesis is that a close relationship exists between internal recycle ratio and $\mathrm{N}_{2} \mathrm{O}$ generation. At present, however, the effects of internal recycle ratio changes on $\mathrm{N}_{2} \mathrm{O}$ emissions in BNR wastewater treatment processes have not been extensively studied.

The purpose of this study is to investigate the effect of internal recycle ratio on $\mathrm{N}_{2} \mathrm{O}$ emission characteristics and production mechanisms in BNR process. Three parallel laboratory-scale $\mathrm{A}^{2} \mathrm{O}$ wastewater treatment processes were acclimated under different internal recycle ratios of $100 \%, 200 \%$, and $300 \%$, and the effect of changes in internal recycle ratio on $\mathrm{N}_{2} \mathrm{O}$ generation in each unit of the $\mathrm{A}^{2} \mathrm{O}$ process was studied. Denitrifier community compositions and gene copy numbers in each unit under different internal recycle ratios were analyzed using a clone library and real-time quantitative PCR (qPCR), targeting functional genes of nosZ.

\section{Materials and methods}

\subsection{Reactor setup and operation}

Three parallel laboratory-scale $\mathrm{A}^{2} \mathrm{O}$ wastewater treatment processes were operated under different internal recycle ratios of $100 \%$, $200 \%$, and $300 \%$. Except for the internal recycle rate, three parallel processes were carried out under same operating parameters, as follows. The $\mathrm{A}^{2} \mathrm{O}$ process had a total effective volume of $50 \mathrm{~L}$ (Fig. 1). The volumes of the anaerobic section, anoxic section, oxic section, and secondary sedimentation tank were $5,10,30$, and $5 \mathrm{~L}$, respectively. The treatment system was seeded with sludge from the aerobic tank of Luotuowan Wastewater Treatment Plant (Xinxiang, China). Influent wastewater from a residential area in Henan Normal University was loaded at a rate of $85 \mathrm{~L} / \mathrm{d}$. Water quality results showed the following contents: COD $175.6 \pm 30.2 \mathrm{mg} / \mathrm{L}$, $\mathrm{NH}_{4}{ }^{+}-\mathrm{N} 38.7 \pm 3.2 \mathrm{mg} / \mathrm{L} \mathrm{NO}_{3}{ }^{-}-\mathrm{N} 1.2 \pm 0.2 \mathrm{mg} / \mathrm{L}, \mathrm{TN} 39.5 \pm 3.3 \mathrm{mg} / \mathrm{L}$, $\mathrm{TP} 7.2 \pm 2.4 \mathrm{mg} / \mathrm{L}$. The water temperature was kept constant at $25^{\circ} \mathrm{C}$ by three temperature controllers in anaerobic, anoxic and oxic sections throughout the research period. The SRT of system and mixed liquor suspended solid (MLSS) concentration of the water was maintained at $15 \mathrm{~d}$ and approximately $3000 \mathrm{mg} / \mathrm{L}$, by controlling the emission amount of excess sludge. The sludge recycle ratio of $100 \%$ was controlled by a peristaltic pump, which brought the sludge from secondary sedimentation tank to anaerobic section with the flow of $85 \mathrm{~L} / \mathrm{d}$ (Fig. 1).

The anaerobic and anoxic sections of the experimental process were stirred by a magnetic stirrer (85-2 Sile Shanghai) at a rotating speed of $500 \mathrm{r} / \mathrm{min}$ to keep the activated sludge suspended in the water. Two dismountable sealing covers were on the top of anaerobic and anoxic section to maintain the anaerobic and anoxic conditions, respectively. The DO of the oxic section was maintained at $2 \mathrm{mg} / \mathrm{L}$ by an air pump with an adjustable air flow meter. A mechanical stirrer was installed in the secondary sedi- mentation tank (US-52 Oteli Beijing) and operated at a rotating speed of $30 \mathrm{r} / \mathrm{min}$. Gas and liquid samples were obtained at the same time; liquid-phase samples were used to measure water quality parameters of $\mathrm{COD}, \mathrm{NH}_{4}{ }^{+}-\mathrm{N}, \mathrm{NO}_{3}{ }^{-}-\mathrm{N}, \mathrm{NO}_{2}{ }^{-}-\mathrm{N}$, TN and TP. All measurements were carried out after the $\mathrm{A}^{2} \mathrm{O}$ process had been acclimated under each internal recycle rate (100\%, 200\%, and $300 \%)$ for over 2 months and reached stable performance, as indicated by the stable COD, $\mathrm{NH}_{4}{ }^{+}-\mathrm{N}$, TN and TP concentrations observed in the effluents.

\subsection{Sampling and analysis methods}

\subsubsection{Sampling for anaerobic section, anoxic section, and secondary sedimentation tank}

A modified closed-chamber technique was used to measure fluxes in non-aerated surfaces (anaerobic section, anoxic section and secondary sedimentation tank) [22]. There were three closed chambers for each one of the non-aerated surfaces. Each tank and its constant chamber had the same diameter. There were flanges at the lower rim of the chamber and the upside of tanks. During gas sampling, closed chambers were fixed on the top of tanks, by joining the flanges. The pressure of the sampling device and joint was checked at each sampling. Four samples were collected from the headspace of the chambers through polytetrafluoroethylene tubes, into 50-mL polypropylene syringes, at 3-min intervals. The gas flux, $F\left(\mathrm{mg} / \mathrm{m}^{2} \mathrm{~min}\right)$, from the liquid surface in the static chamber was calculated using the equation:

$F=\left(\frac{V}{A}\right) \rho\left(\frac{\Delta c}{\Delta t}\right)$

where $V\left(\mathrm{~m}^{3}\right)$ is the volume from the liquid level to the top of chamber, $A\left(\mathrm{~m}^{2}\right)$ is the enclosed surface area, $\rho\left(\mathrm{mg} / \mathrm{m}^{3}\right)$ is the density of the gas at the temperature recorded in the chamber, and $\Delta c$ $(\mathrm{v} / \mathrm{v}) / \Delta t(\mathrm{~min})$ is the change of gas concentration in the chamber per unit time during sampling. The gas density $(\rho)$ is calculated by the equation:

$\rho=\frac{10^{-6} M P}{R T}$

where $M$ is the molecular weight of $\mathrm{N}_{2} \mathrm{O}(44.02 \mathrm{~g} / \mathrm{mol}), P$ is the atmospheric pressure $(1 \mathrm{~atm}), R$ is the gas constant (0.082 Latm/K mol), $T$ is the temperature $(\mathrm{K})$.

\subsubsection{Oxic section sampling}

During gas sampling, a closed gas-tight chamber with a gassampling outlet was fixed to the tank. The pressure of the sampling device and joint was checked at each sampling. The entire system was gas-tight and the effluent air was collected into gas sampling bags. Three parallel samples were taken at each sampling, and the gas flux, $F\left(\mathrm{mg} / \mathrm{m}^{2} \mathrm{~min}\right)$, was calculated by

$F=\frac{\rho c Q_{\mathrm{a}}}{A}$

where $\rho\left(\mathrm{mg} / \mathrm{m}^{3}\right)$ is the density of the gases at the sampling temperature, $c(\mathrm{v} / \mathrm{v})$ is the sample gas concentration, $Q_{\mathrm{a}}\left(\mathrm{m}^{3} / \mathrm{min}\right)$ is the aeration rate, and $A\left(\mathrm{~m}^{2}\right)$ is the total surface area.

\subsubsection{Dissolved gas sampling}

To collect gas samples dissolved in wastewater, the headspace gas method described by Kimochi et al. [23] was used. Thirty milliliter each of water and argon gas were sealed in a $50-\mathrm{mL}$ syringe; $1 \mathrm{~mL}$ of $20 \mathrm{mmol} / \mathrm{L}$ mercury(II) chloride was added to this mixture to prevent biological degradation. After vigorous shaking, the syringe was left at room temperature for $1 \mathrm{~h}$ without moving. The resulting gas phase in the syringe was collected as a gas sample. 


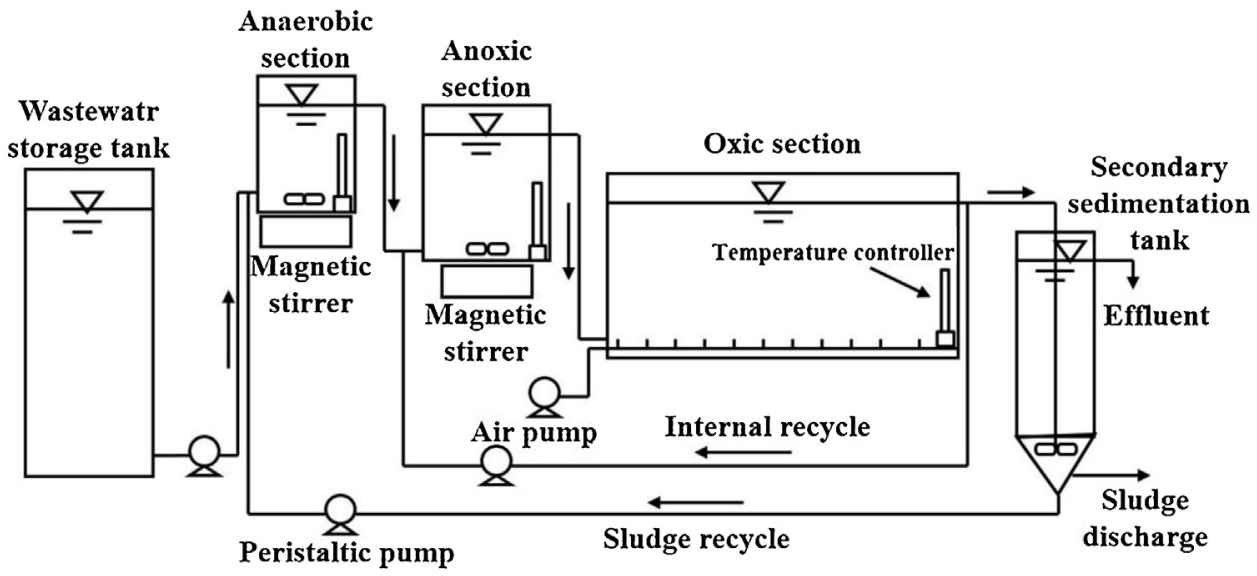

Fig. 1. Schematic of the experimental process.

Dissolved gas concentrations can be calculated using Henry's Law through the equilibrium headspace gas concentrations.

\subsection{4. $\mathrm{N}_{2} \mathrm{O}$ and water quality analysis}

A gas chromatograph (HP-Chemistation 5890, Agilent Co., Ltd., USA) with an electron capture detector (ECD) was used to analyze $\mathrm{N}_{2} \mathrm{O}$ concentrations. $\mathrm{COD}, \mathrm{NH}_{4}{ }^{+}-\mathrm{N}, \mathrm{NO}_{2}{ }^{-}-\mathrm{N}, \mathrm{NO}_{3}{ }^{-}-\mathrm{N}$, and TN were analyzed according to standard methods [24]. The measurements of oxidation-reduction potential (ORP) and DO of wastewater were conducted using WTW3110 ORP (made in Germany) and WTWMulti 340i DO (made in Germany), respectively.

\subsubsection{Activity measurements}

The activities of nitrate reductase, nitrite reductase, and nitrous oxide reductase were determined anaerobically at $25^{\circ} \mathrm{C}$. Activated sludge was washed in $25 \mathrm{mmol} / \mathrm{L}$ HEPES buffer ( $N$-[2-hydroxyethyl] piperazine- $N^{\prime}$-[2-ethanesulfonic acid], pH 7.2). TMPD ( $N, N, N^{\prime}, N^{\prime}-$ tetramethyl-p-phenylenediamine [Sigma]) and ascorbate (Sigma) were used as the electron donor couple [6]. EDTA $(1.0 \mathrm{mmol} / \mathrm{L})$ was added to prevent possible chemical reduction [25]. The amount of chemical reduction was estimated by control experiments, using pasteurized $\left(2 \mathrm{~min}, 95^{\circ} \mathrm{C}\right)$ activated sludge. Nitrate and nitrite disappearance was followed by taking samples at 2-min intervals from a reaction chamber $(100 \mathrm{~mL})$. Nitrous oxide disappearance was determined by measuring the dissolved $\mathrm{N}_{2} \mathrm{O}$ by the method described in Section 2.2.3. At the initiation of the reactions, the concentrations of $\mathrm{NO}_{3}{ }^{-}-\mathrm{N}, \mathrm{NO}_{2}-\mathrm{N}$ and dissolved $\mathrm{N}_{2} \mathrm{O}$ were 25,5 and $2.0 \times 10^{-2} \mathrm{mg} / \mathrm{L}$, respectively.

\section{3. $\mathrm{N}_{2} \mathrm{O}$ mass balance calculation}

The $\mathrm{N}_{2} \mathrm{O}$ generated in each unit of the $\mathrm{A}^{2} \mathrm{O}$ process can be calculated using Eqs. (4)-(7).

$$
\begin{aligned}
G_{\mathrm{An}} & =\frac{E_{\mathrm{An}}+C_{\mathrm{An}} \times\left(1+R_{1}\right) Q-C_{\mathrm{In}} \times Q-C_{\mathrm{SST}} \times R_{1} Q}{Q} \\
G_{\mathrm{Ax}} & =\frac{E_{\mathrm{Ax}}+C_{\mathrm{Ax}} \times\left(1+R_{1}+R_{2}\right) Q-C_{\mathrm{An}} \times\left(1+R_{1}\right) Q-C_{\mathrm{Ae}} \times R_{2} Q}{Q}
\end{aligned}
$$

$G_{\mathrm{Ae}}=\frac{E_{\mathrm{Ae}}+C_{\mathrm{Ae}} \times\left(1+R_{1}+R_{2}\right) Q-C_{\mathrm{Ax}} \times\left(1+R_{1}+R_{2}\right) Q}{Q}$

$G_{\mathrm{SST}}=\frac{E_{\mathrm{SST}}+C_{\mathrm{SST}} \times\left(1+R_{1}\right) Q-C_{\mathrm{Ae}} \times\left(1+R_{1}\right) Q}{Q}$ where $G_{\mathrm{An}}, G_{\mathrm{Ax}}, G_{\mathrm{Ae}}$, and $G_{\mathrm{SST}}(\mathrm{mg} / \mathrm{L})$ are the amounts of $\mathrm{N}_{2} \mathrm{O}$ generated in the anaerobic section, anoxic section, oxic section, and secondary sedimentation tank, respectively; $E_{\mathrm{An}}, E_{\mathrm{Ax}}, E_{\mathrm{Ae}}$, and $E_{\mathrm{SST}}$ $(\mathrm{mg} / \mathrm{d})$ are the amounts of $\mathrm{N}_{2} \mathrm{O}$ emitted from the anaerobic section, anoxic section, oxic section, and secondary sedimentation tank, respectively; $C_{\mathrm{In}}, C_{\mathrm{An}} C_{\mathrm{Ax}}, C_{\mathrm{Ae}}$, and $C_{\mathrm{SST}}(\mathrm{mg} / \mathrm{L})$ are the concentrations of dissolved $\mathrm{N}_{2} \mathrm{O}$ in influent, anaerobic section, anoxic section, oxic section, and secondary sedimentation tank, respectively; $R_{1}(\%)$ is the sludge return ratio; and $R_{2}(\%)$ is the internal recycle ratio; $Q$ $(\mathrm{L} / \mathrm{d})$ is the influent flow rate.

\subsection{DNA extraction, PCR amplification, and sequencing}

Isolation of total DNA was accomplished with a Magnetic System-16 (TanBead, Taiwan) setup. Primers nosZ-F (AGAACGACCAGCTGATCGACA) and nosZ-R (TCCATGGTGACG CCG TGGTTG) were used to amplify the gene segment of nosZ encoding nitrous oxide reductase [26]. The PCR amplification reaction was performed using a Gene AmpR PCR system (9700, AB, USA) at a final volume of $50 \mu \mathrm{L}$; the PCR program was as follows: followed by 25 cycles of $94^{\circ} \mathrm{C}$ for $30 \mathrm{~s}, 56^{\circ} \mathrm{C}$ for $30 \mathrm{~s}$, and $72^{\circ} \mathrm{C}$ for $90 \mathrm{~s}$. After purification by an agarose-gel extraction kit (Dingguo, China), the PCR products were ligated and transformed into Escherichia coli DH5 $\alpha$ competent cells. The positive clones were selected cultured on LB medium with X-gal, IPTG and Amp to submit for sequencing using the $A B I 3730 D X L$ DNA sequencer ( $A B, U S A)$.

\subsection{Clone library construction and phylogenetic analysis of sequences in the clone libraries}

All sequences were manually checked and trimmed to exclude vector sequences and were then checked for chimeras using Bellerophon on the Greengenes website (http://greengenes.lbl. gov/). After excluding chimeras and false-positive clones, other sequences of each sample were aligned and were classified into universal operational taxonomic units (OTUs) at a threshold of 97\% minimum similarity. Individual sequences were also assigned into OTUs to identify bacterial populations in sludge from different sampling sites. The representative sequence of each OTU in group-specific libraries was aligned to the NCBI database by BLAST. To identify the phylogenetic affiliation of all OTUs, a phylogenetic tree including representative sequences of each OTU and related sequences from the previous NCBI database was constructed using the neighbor joining algorithm with MEGA version 6.1. 
Table 1

ORPs in each unit under three operation modes.

\begin{tabular}{llll}
\hline & \multicolumn{3}{l}{ ORP $(\mathrm{mv})$} \\
\cline { 2 - 4 } & Anaerobic section & Anoxic section & Oxic section \\
\hline $100 \%$ & $-213.2 \pm 30.5$ & $-82.3 \pm 21.3$ & $123.4 \pm 32.3$ \\
$200 \%$ & $-209.2 \pm 25.8$ & $-74.2 \pm 19.2$ & $119.6 \pm 29.1$ \\
$300 \%$ & $-198.4 \pm 27.1$ & $-67.8 \pm 15.2$ & $116.7 \pm 38.4$ \\
\hline
\end{tabular}

\subsection{Real-time quantitative $P C R$}

Denitrifying bacterial counts were determined by qPCR quantification based on the nosZ gene, using the primers nosZ-F: 5-AGAACGACCAGCTGATCGACA-3 and nosZ-R: 5TCCATGGTGACGCCGTGGTTG-3 [26]. For nosZ gene PCR, $2 \mu \mathrm{L}$ of extracted DNA was added to a PCR reaction mixture containing $12.5 \mu \mathrm{L}$ of SYBR Premix Ex Taq (TaKaRa, Japan), $0.5 \mu \mathrm{L}$ of nosZ-F (10 $\mu \mathrm{M}$ each), $0.5 \mu \mathrm{L}$ of nosZ-R ( $10 \mu \mathrm{M}$ each), and $9.5 \mu \mathrm{L}$ of $\mathrm{dH}_{2} \mathrm{O}$. qPCR was performed using a TaKaRa PCR Thermal Cycler Dice real-time PCR system (TaKaRa Code: TP800) with an initial denaturation step of $95^{\circ} \mathrm{C}$ for $5 \mathrm{~min}$, followed by 45 cycles of $95^{\circ} \mathrm{C}$ for $30 \mathrm{~s}$ and $65^{\circ} \mathrm{C}$ for $30 \mathrm{~s}$. Denitrifying bacterial nosZ from the samples was calculated using the quantitative software available with the PCR instrument using serially diluted PCR products to generate a standard curve. Sample concentrations of nosZ were determined by comparison of the crossing threshold cycle $(\mathrm{Ct})$, against the standard curve crossing threshold $(\mathrm{Ct})$ produced to count copies of target DNA per sample. The numbers of standard DNA for the primer set were adjusted as a series of tenfold dilutions ranging from $1.0 \times 10^{2}$ (nosZ gene) copies $\mathrm{mL}^{-1}$ to $1.0 \times 10^{7}$ (nosZ gene) copies $\mathrm{mL}^{-1}$. In the standard curve, the linear correlation $\left(R^{2}=0.999\right)$ was observed for six orders of magnitude ranging from $10^{2}$ to $10^{7}$ gene copies per mL of standard DNA.

\section{Results and discussion}

\subsection{Performance of $A^{2} O$ process with different internal recycle ratios}

Fig. 2 shows $\mathrm{COD}, \mathrm{NH}_{4}{ }^{+}-\mathrm{N}, \mathrm{NO}_{2}{ }^{-}-\mathrm{N}, \mathrm{NO}_{3}{ }^{-}-\mathrm{N}, \mathrm{TN}$ and TP concentrations in each unit of the $\mathrm{A}_{2} \mathrm{O}$ process with internal recycle ratios of $100 \%, 200 \%$, and $300 \%$. Table 1 shows the ORP of sludge mixtures in each unit.

High COD, $\mathrm{NH}_{4}{ }^{+}-\mathrm{N}$ and TP removal were observed among the three operating modes evaluated in this work, and the removal characteristics in each operating mode were similar (Fig. 2). COD and $\mathrm{NH}_{4}{ }^{+}-\mathrm{N}$ removal rates slightly improved as the internal recycle ratio increased from $100 \%$ to $300 \%$. These results reveal that the internal recycle ratio could influence organic matter oxidation in $\mathrm{A}^{2} \mathrm{O}$ process. Variations in $\mathrm{COD}, \mathrm{NH}_{4}^{+}-\mathrm{N}, \mathrm{NO}_{3}{ }^{-}-\mathrm{N}$, TN and TP concentration detected among the units showed the distinctive functions of the anaerobic, anoxic, and oxic sections in an $\mathrm{A}^{2} \mathrm{O}$ process. While the oxic section is assumed responsible for organic matter oxidation and $\mathrm{NH}_{4}{ }^{+}-\mathrm{N}$ nitrification, denitrification mainly occurs in the anoxic section. Phosphorus uptake and release was processed in oxic and anaerobic section, respectively.

Denitrification effects in the anoxic section were enhanced as the internal recycle ratio increased from $100 \%$ to $300 \%$; the TN decreased amount was increased from 1.5 to $7.8 \mathrm{mg} / \mathrm{L}$ in this unit. Thus, the TN removal rate significantly increased from $45.8 \%$ to 61.9\% (Fig. 2). $\mathrm{NO}_{3}{ }^{-}-\mathrm{N}$ concentrations in each unit decreased with the increased internal recycle rate in this work (Fig. 2). On one hand, this phenomenon may be ascribed to the fact that increase in recycle liquid ratio provides more nitrates to the denitrification reactor and thus improves overall nitrogen removal rates. COD in the anoxic section also decreased with increasing internal recycle ratio,
Table 2

$\mathrm{N}_{2} \mathrm{O}$ generation under the three operating modes studied.

\begin{tabular}{llll}
\hline Parameters & $100 \%$ & $200 \%$ & $300 \%$ \\
\hline Anaerobic section $(\mathrm{mg} / \mathrm{L})$ & $0.39 \times 10^{-2}$ & $1.05 \times 10^{-2}$ & $1.94 \times 10^{-2}$ \\
Anoxic section $(\mathrm{mg} / \mathrm{L})$ & $0.60 \times 10^{-2}$ & $1.92 \times 10^{-2}$ & $3.35 \times 10^{-2}$ \\
Oxic section $(\mathrm{mg} / \mathrm{L})$ & $1.34 \times 10^{-2}$ & $2.08 \times 10^{-2}$ & $2.65 \times 10^{-2}$ \\
Secondary sedimentation tank $(\mathrm{mg} / \mathrm{L})$ & $1.14 \times 10^{-2}$ & $1.54 \times 10^{-2}$ & $1.87 \times 10^{-2}$ \\
Total $\mathrm{N}_{2} \mathrm{O}$ generation $(\mathrm{mg} / \mathrm{L})$ & $3.47 \times 10^{-2}$ & $6.59 \times 10^{-2}$ & $9.81 \times 10^{-2}$ \\
$\mathrm{~N}_{2} \mathrm{O}-\mathrm{N}$ conversion ratio $(\%)$ & 0.14 & 0.20 & 0.21 \\
\hline
\end{tabular}

probably because more electron donors are needed during $\mathrm{NO}_{x}$ $\left(\mathrm{NO}_{3}{ }^{-}\right.$and $\left.\mathrm{NO}_{2}{ }^{-}\right)$denitrification. On the other hand, assimilation of dissolved inorganic nitrogen by heterotrophic microorganisms is a potentially large contributor to TN removal during the anoxic phase of treatment, and adequate $\mathrm{NO}_{3}{ }^{-}-\mathrm{N}$ provided by high internal recycle ratios enhances cell assimilation during this phase. Thus, COD and $\mathrm{NH}_{4}{ }^{+}-\mathrm{N}$ show higher removal rates under higher internal recycle ratios (Fig. 2). The economic cost is directly related to the internal recycle rate, as an increase of the ratio from 1 to 5 implies approximately a five times higher energy consumption [27]. Therefore, to ensure a cost efficient project, we did not conduct experiments with recycle rates higher than $300 \%$.

ORP monitoring results, which increased from the anaerobic to the oxic section (Table 1) under all operating modes, also revealed the distinct functions of each of the units in the $\mathrm{A}^{2} \mathrm{O}$ process. $\mathrm{NO}_{2}{ }^{-}-$ $\mathrm{N}$ accumulation occurred in the anaerobic and anoxic sections, but not in the oxic section, under the three operating conditions (Fig. 2). As the internal recycle ratio increased, so did the $\mathrm{NO}_{2}{ }^{-}-\mathrm{N}$ concentrations. $\mathrm{NO}_{2}{ }^{-}-\mathrm{N}$ was produced in denitrification process for the nitrate reductase is more competitive in the competition of electron donor between nitrate reductase and nitrite reductase [28]. As the recycle liquid brought more $\mathrm{NO}_{3}{ }^{-}-\mathrm{N}$ to anoxic section under high internal recycle ratios, the first step of denitrification was enhanced, which was shown as decreased TN concentration.

\section{2. $\mathrm{N}_{2} \mathrm{O}$ generation and emission of $A^{2} \mathrm{O}$ under different internal recycle ratios}

The $\mathrm{N}_{2} \mathrm{O}$ mass balances of dissolved liquid and gas phase $\mathrm{N}_{2} \mathrm{O}$ obtained during $\mathrm{A}^{2} \mathrm{O}$ under different internal recycle ratios are shown in Fig. 3.

In this study, $\mathrm{N}_{2} \mathrm{O}$ emission was detected in all units of the $\mathrm{A}^{2} \mathrm{O}$ treatment process studied (Fig. 3). Under each operation mode, maximal $\mathrm{N}_{2} \mathrm{O}$ emission was detected in oxic section, whereas minimal $\mathrm{N}_{2} \mathrm{O}$ emission was found in the secondary settling tank. Dissolved $\mathrm{N}_{2} \mathrm{O}$ concentration among the units varied considerably with variations in internal recycle ratios. At an internal recycle ratio of $100 \%$, the secondary settling tank reflected the highest concentration of dissolved $\mathrm{N}_{2} \mathrm{O}(1.13 \mathrm{~g} / \mathrm{d})$. As the internal recycle ratio increased, the internal recycle liquid flow increased and the anoxic section showed the highest concentration of dissolved $\mathrm{N}_{2} \mathrm{O}$. Dissolved $\mathrm{N}_{2} \mathrm{O}$ amounts taken up by the effluent under internal recycle ratio of $100 \%, 200 \%$, and $300 \%$ respectively totaled $19.3 \%, 12.0 \%$, and $9.4 \%$ of the total $\mathrm{N}_{2} \mathrm{O}$ generation. Most of this dissolved $\mathrm{N}_{2} \mathrm{O}$ is probably released to the atmosphere because the average background $\mathrm{N}_{2} \mathrm{O}$ concentration was $319 \mathrm{ppb}$ [1].

$\mathrm{N}_{2} \mathrm{O}$ production in the $\mathrm{A}^{2} \mathrm{O}$ process generally increased with increasing internal recycle ratio (Table 2). During wastewater treatment process, $\mathrm{N}_{2} \mathrm{O}$ is first generated in the liquid phase and then stripped from water to the atmosphere in the gas phase by mechanical stirring and aeration. Considering differences in agitation conditions, $\mathrm{N}_{2} \mathrm{O}$ production and emission may not occur in the same unit. To identify the increased $\mathrm{N}_{2} \mathrm{O}$ emission source in $\mathrm{A}^{2} \mathrm{O}$ treatment process, the $\mathrm{N}_{2} \mathrm{O}$ generated in each unit was calculated according to Eqs. (4)-(7) (Table 2). 

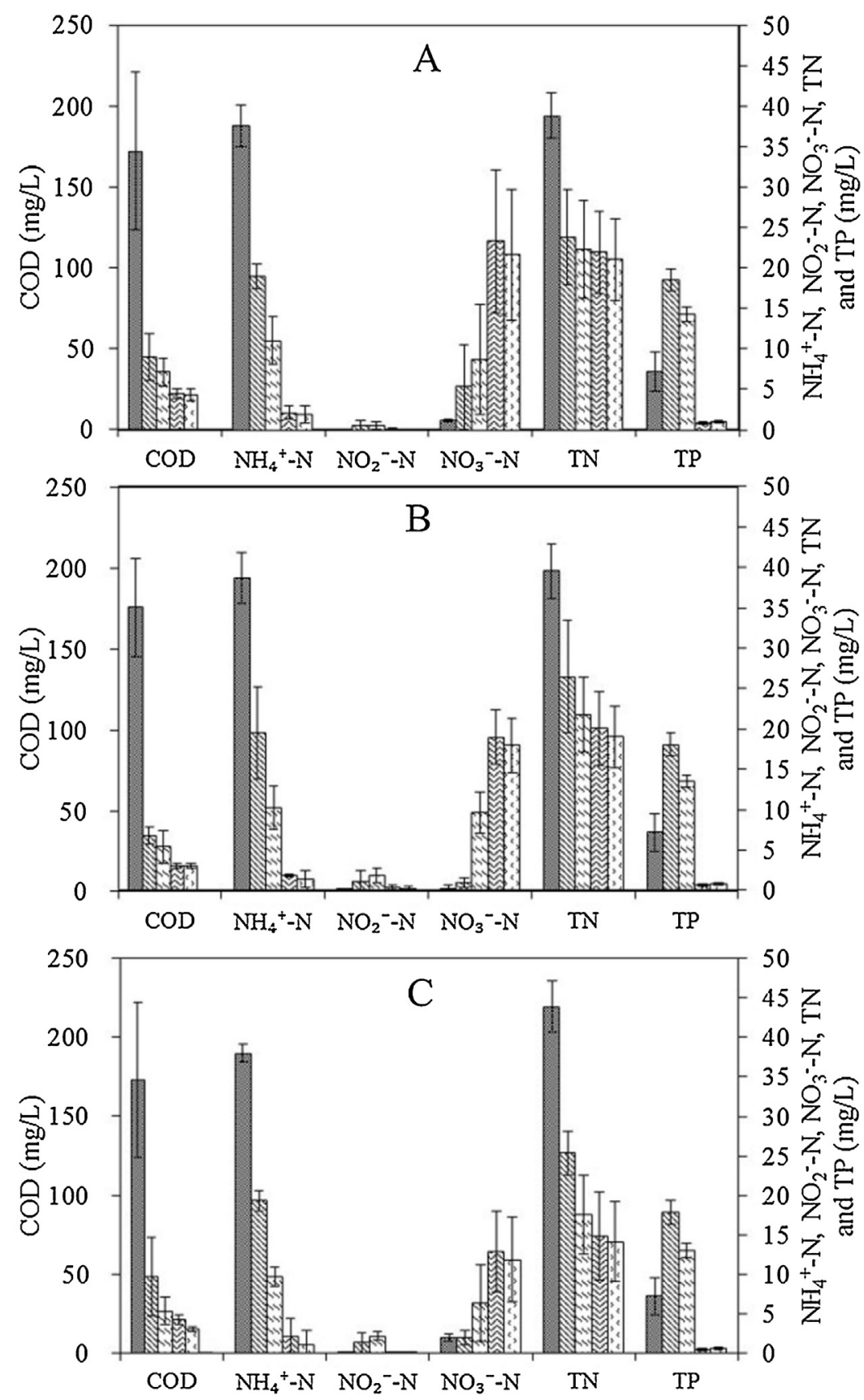

Fig. 2. Pollutant concentrations in each unit under different internal recycle ratios: (A) internal recycle ratio of $100 \%$, (B) internal recycle ratio of $200 \%$, and (C) internal recycle ratio of $300 \%$.

With the increased internal recycle ratio, $\mathrm{N}_{2} \mathrm{O}$ emission increments were highest in the anoxic section among the units observed (Table 2), but part of this $\mathrm{N}_{2} \mathrm{O}$ is released in the oxic section (Fig. 3 ). Denitrification mainly occurs in the anoxic section, and $\mathrm{N}_{2} \mathrm{O}$ is produced as an intermediate product of this process [2]. As the internal recycle ratio increased, more $\mathrm{NO}_{3}{ }^{-}-\mathrm{N}$ was brought to the anoxic section (Fig. 2), and the availability of substrates for denitrification increased. More DO from the oxic section is also brought to the anoxic section. DO of $0.24 \pm 0.04,0.37 \pm 0.07$, and $0.46 \pm 0.06 \mathrm{mg} / \mathrm{L}$ were detected in the anoxic section at internal recycle ratios of $100 \%, 200 \%$, and $300 \%$, respectively. Oxygen inhibits both the synthesis and activity of denitrification enzymes [2]. Coupled with the variation of $\mathrm{NO}_{3}{ }^{-}-\mathrm{N}$ concentration and $\mathrm{NO}_{2}{ }^{-}-\mathrm{N}$ accumulation phenomenon in anoxic section, the impact from increase of internal

Table 3

Activities of nitrate reductase, nitrite reductase and nitrous oxide reductase in anoxic section under the three operating modes.

\begin{tabular}{|c|c|c|c|}
\hline & $100 \%$ & $200 \%$ & $300 \%$ \\
\hline Nitrate reductase activities (mg N/g MLSS min) & $38.1 \pm 3.0 \times 10^{-2}$ & $37.7 \pm 2.3 \times 10^{-2}$ & $36.3 \pm 1.5 \times 10^{-2}$ \\
\hline Nitrite reductase activities (mg N/g MLSS min) & $33.4 \pm 1.3 \times 10^{-2}$ & $29.3 \pm 1.8 \times 10^{-2}$ & $25.1 \pm 1.3 \times 10^{-2}$ \\
\hline Nitrous oxide reductase activities (mg N/g MLSS min) & $9.8 \pm 0.5 \times 10^{-2}$ & $5.3 \pm 0.6 \times 10^{-2}$ & $2.2 \pm 0.2 \times 10^{-2}$ \\
\hline
\end{tabular}



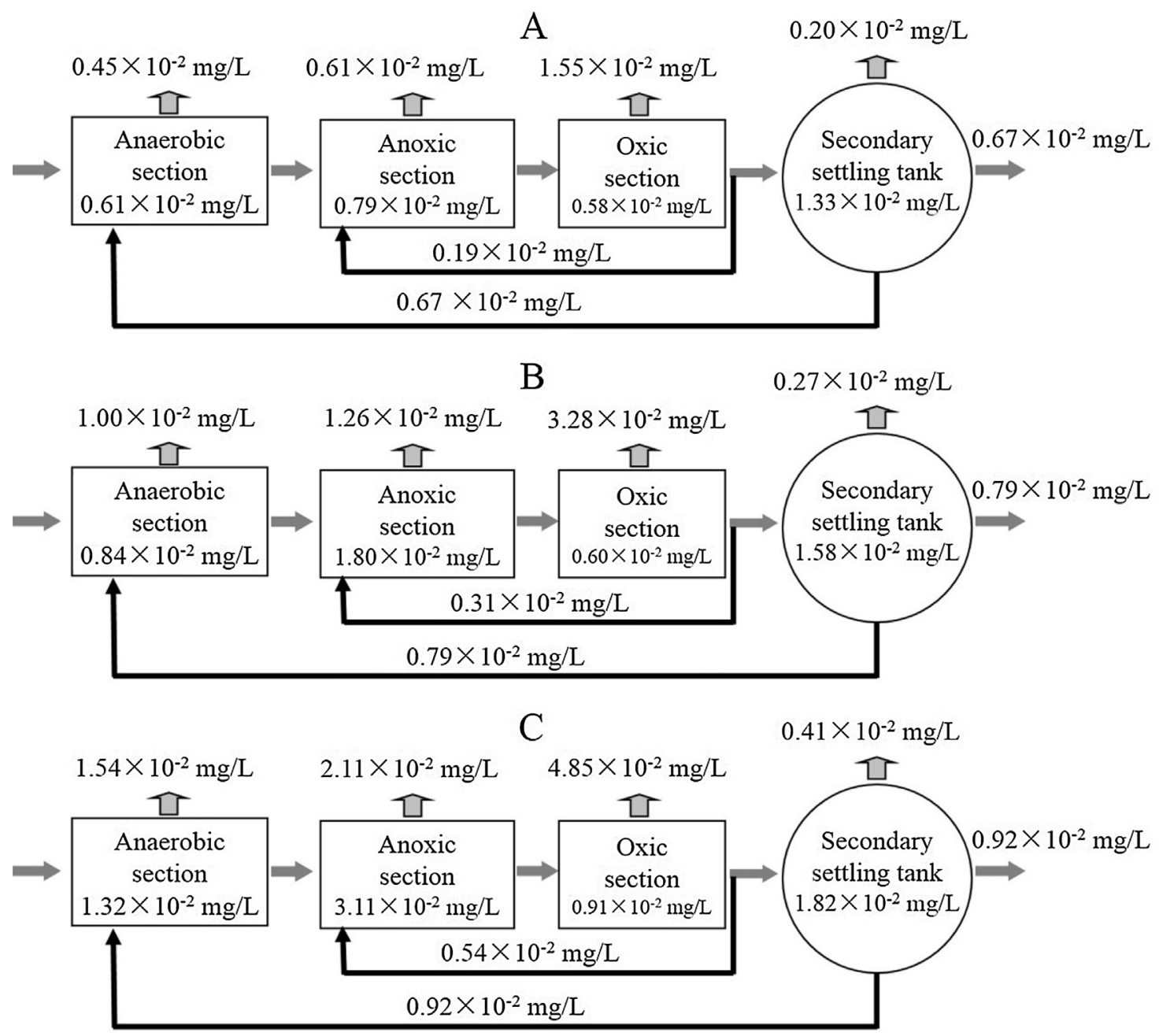

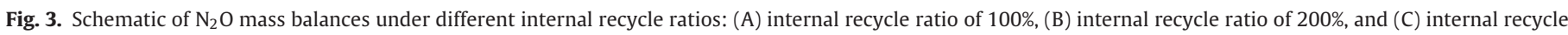
ratio of $300 \%$.

recycle rate on denitrification enzymes was in this order: nitrous oxide reductase $>$ nitrite reductase $>$ nitrate reductase (Table 3 ). This result is in agreement with the results reported by Otte et al. [6], showing that $\mathrm{N}_{2} \mathrm{O}$ reductase is more sensitive to oxygen than other enzymes, increased $\mathrm{N}_{2} \mathrm{O}$ emissions during denitrification may be observed when low concentrations of oxygen are present in the anoxic section. This inference may explain why both nitrogen removal rates and $\mathrm{N}_{2} \mathrm{O}$ generation in the anoxic section increased with increasing internal recycle ratio.

$\mathrm{N}_{2} \mathrm{O}$ was observed at concentrations of $1.34 \times 10^{-2}$ and $2.08 \times 10^{-2} \mathrm{mg} / \mathrm{L}$ during oxic production at internal recycle ratios of $100 \%$ and $200 \%$, respectively, these values being highest under their operation modes. In addition, when the internal recycle ratio was $300 \%$, the oxic section produced the second highest amount of $\mathrm{N}_{2} \mathrm{O}\left(2.65 \times 10^{-2} \mathrm{mg} / \mathrm{L}\right)$ among all of the units (anoxic section was $3.35 \times 10^{-2} \mathrm{mg} / \mathrm{L}$ ). Several researchers have shown that $\mathrm{N}_{2} \mathrm{O}$ emissions in full-scale WWTPs primarily occur in the oxic section $[10,29,30]$. The phenomenon observed in this study agrees with these results. While $\mathrm{N}_{2} \mathrm{O}$ is not present as an intermediate in the main catabolic pathway of nitrification, AOB are known to produce $\mathrm{N}_{2} \mathrm{O}$, which is predominantly associated with the nitrifier denitrification pathways [28]; $\mathrm{N}_{2} \mathrm{O}$ emissions due to chemical reactions of unstable biological intermediates have also been observed (in pure culture experiment) [3]. Wunderlin et al. [31] reported that $\mathrm{N}_{2} \mathrm{O}$ production from chemical reactions in active sludge systems is of minor importance. Thus, $\mathrm{N}_{2} \mathrm{O}$ generation in the oxic section may be attributed to nitrifier denitrification produced by AOB.

Rapid changes in environmental conditions may also explain the higher $\mathrm{N}_{2} \mathrm{O}$ emissions observed at higher internal recycle ratios [32,33]. Several researchers have found that $\mathrm{N}_{2} \mathrm{O}$ generation increases markedly when the environmental conditions change. High internal recycle ratios accelerate liquid recycle between units and promote changes in other process conditions, especially DO, thereby leading to increased $\mathrm{N}_{2} \mathrm{O}$ production. This hypothesis may also explain why the $\mathrm{N}_{2} \mathrm{O}$ generated in every unit increased with increasing internal recycle ratio.

In contrast to expectations, the secondary settling tank produced $\mathrm{N}_{2} \mathrm{O}$ during wastewater treatment; $32.9 \%, 23.4 \%$, and $19.1 \%$ of the total $\mathrm{N}_{2} \mathrm{O}$ were generated under internal ratios of $100 \%$, $200 \%$ and $300 \%$, respectively. This $\mathrm{N}_{2} \mathrm{O}$ contribution is speculated to originate from the denitrification process because AOB and denitrification bacteria could denitrify $\mathrm{NO}_{x}$ to $\mathrm{N}_{2} \mathrm{O}$ or $\mathrm{N}_{2}$ at low DO conditions [2]. High $\mathrm{NO}_{3}{ }^{-}-\mathrm{N}$ and low COD concentrations, which benefit $\mathrm{N}_{2} \mathrm{O}$ production, were also detected in the secondary settling tank (Fig. 2).

\subsection{Analysis of nosZ-containing microbial communities}

The nosZ gene encoding nitrous oxide reductase is known to be unique to denitrifying bacteria; the presence of this gene indi- 
cates that the bacterial species under consideration is capable of reducing $\mathrm{N}_{2} \mathrm{O}$ to $\mathrm{N}_{2}$. To investigate the mechanisms of $\mathrm{N}_{2} \mathrm{O}$ emissions, the compositions of nosZ-containing bacterial communities in each unit under three operating modes were analyzed using clone libraries (Fig. 4). qPCR assay targeting the nosZ gene was also conducted (Fig. 5).

Based on the phylogenetic tree obtained, similarities among denitrifying bacteria containing the nosZ gene were observed under different internal recycle ratios. Pseudomonas sp., Azospirillum sp., Mesorhizobium sp., Pseudomonas lini, and other uncultured bacteria were detected. These results imply that bacterial populations in the bioreactor are only slightly affected by changes in recycle ratio when the influent quality and inoculated sludge applied are held constant.

qPCR showed distinct differences in nosZ gene copy number with variations in internal recycle ratio. When recycle ratio increased from $100 \%$ to $200 \%$, nosZ gene copies in $A^{2} O$ system decreased sharply from over $1.0 \times 10^{6}$ to less than $6.0 \times 10^{5}$. However, nosZ gene copies between internal recycle ratios of $200 \%$ and $300 \%$ showed only slightly disparities. nosZ gene copy numbers among the three operating modes were as follows: anaerobic section > anoxic section > oxic section. Therefore, decreases in nosZ gene copy number during $\mathrm{A}^{2} \mathrm{O}$ with increasing internal recycle ratio are closely related to the DO environment of each unit during treatment. It is known that nosZ gene encoding nitrous oxide reductase is largely unique to denitrifying bacteria and has recently been used for the detection of denitrifier-specific DNA [34]. Oxygen inhibits denitrification by providing a better electron acceptor for denitrifying populations to generate energy, resulting in deteriorated denitrification bacteria at high DO concentrations [35]. High internal ratios bring about significant changes in the process conditions between the anaerobic and anoxic sections [33]. In this system, DO of anoxic section was increased from $0.24 \pm 0.04$ to $0.46 \pm 0.06 \mathrm{mg} / \mathrm{L}$ with internal recycle rate elevated from $100 \%$ to $300 \%$, and the transition of activity sludge between anoxic and oxic section (DO was $2.0 \mathrm{mg} / \mathrm{L}$ ) became more continually, which was disadvantageous for nosZ gene-containing bacteria. Although increasing internal recycle ratios brought more substrates for denitrification to the anaerobic and anoxic sections, DO circumstance affecting nosZ gene-containing microorganisms was observable. Reductions in nosZ gene copy numbers reveal that the denitrification capacity of the system for reducing $\mathrm{N}_{2} \mathrm{O}$ to $\mathrm{N}_{2}$ is decreased. This hypothesis may explain why $\mathrm{N}_{2} \mathrm{O}$ generation increases with increasing internal recycle ratio.

In this study, functional gene expression was affected largely than the bacterial community composition by variations in operating parameters of internal recycle rate. The bacterial population did not change significantly, but the numbers of functional genes were obviously altered under different internal recycle ratios. These results demonstrate that $\mathrm{N}_{2} \mathrm{O}$ emission reductions could be achieved by regulating the expression of functional genes under different operating parameters. Practically, several strategies have been reported to mitigate $\mathrm{N}_{2} \mathrm{O}$ emissions from wastewater denitrification [35]. Based on this research, ensuring sufficient anoxic HRT, bioaugmentation with the $\mathrm{N}_{2} \mathrm{O}$-reducing denitrifier Pseudomonas stutzeri, choosing methanol over ethanol and adding copper ions $(10-100 \mathrm{mg} / \mathrm{L})$ may reduce $\mathrm{N}_{2} \mathrm{O}$ generation and simultaneously enhance $\mathrm{TN}$ removal under high internal recycle rate for $\mathrm{A}_{2} \mathrm{O}$ process $[34,36,37]$.

\section{Conclusion}

Internal recycle ratio has a significant impact on nitrogen removal and $\mathrm{N}_{2} \mathrm{O}$ production in $\mathrm{A}^{2} \mathrm{O}$ treatment process. The $\mathrm{N}_{2} \mathrm{O}$ generation and nitrogen removal rate both increased significantly

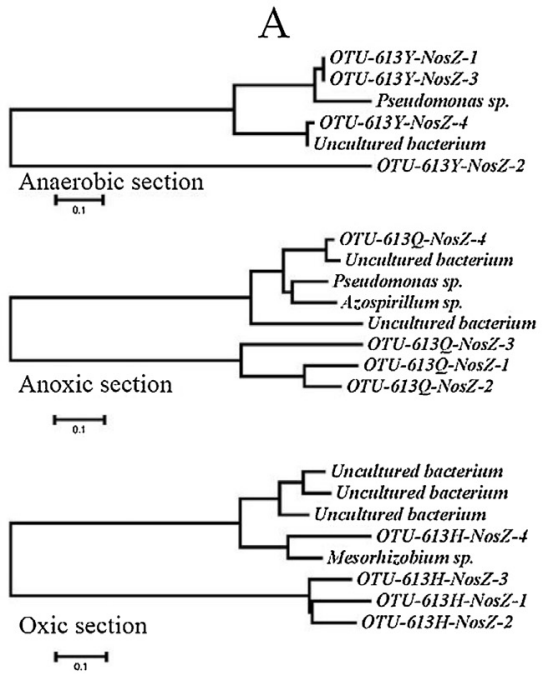

B

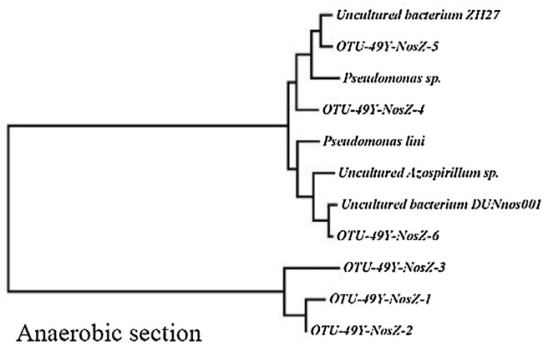

$\longmapsto$

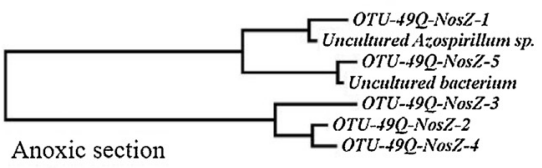

$\longmapsto 0.1$
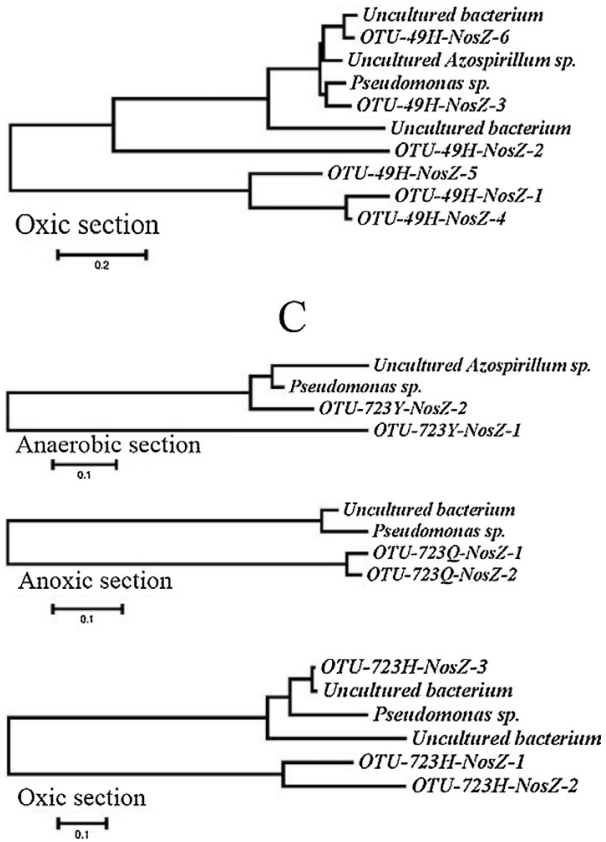

Fig. 4. Neighbor-joining phylogenetic tree based on partial sequences of nosZ: (A) internal recycle ratio of $100 \%$, (B) internal recycle ratio of $200 \%$, and (C) internal recycle ratio of $300 \%$. 


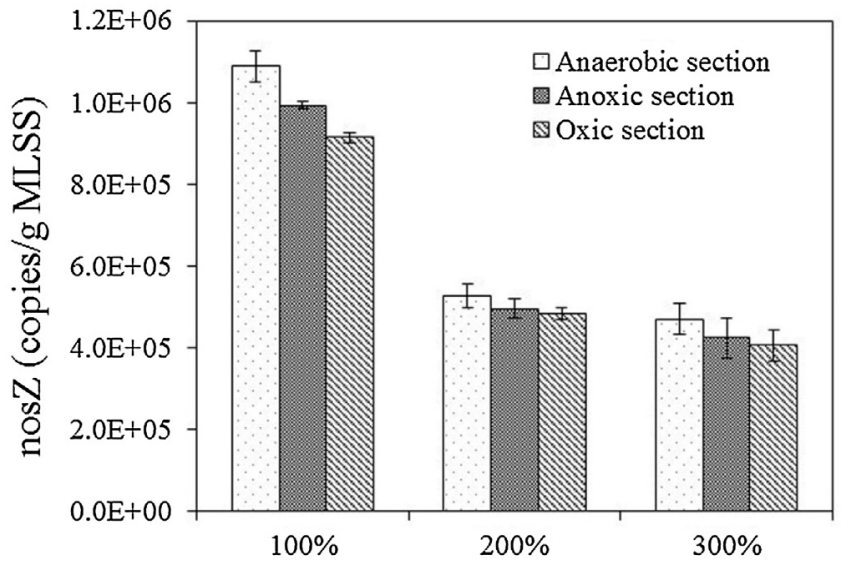

Fig. 5. NosZ gene copy numbers in each $A^{2} \mathrm{O}$ unit under different internal recycle ratios.

with increasing internal recycle ratio from $100 \%$ to $300 \%$, due to more $\mathrm{NO}_{3}{ }^{-}-\mathrm{N}$ and oxygen brought to anoxic section. In this study, improvements in pollutant removal rate and $\mathrm{N}_{2} \mathrm{O}$ reduction revealed apparently a contradiction. In WWTPs, balance must be established between TN removal effects and $\mathrm{N}_{2} \mathrm{O}$ production. New evaluation systems of wastewater treatment processes considering water quality and $\mathrm{N}_{2} \mathrm{O}$ emissions may be considered in future research. Moreover, $\mathrm{N}_{2} \mathrm{O}$ reductase is closely related with $\mathrm{N}_{2} \mathrm{O}$ generation and more sensitive to oxygen than nitrate reductase and nitrite reductase. Higher internal recycle rate could inhibit the nosZ gene-containing bacteria in treatment process, thereby the system revealed decreased ability to reduce $\mathrm{N}_{2} \mathrm{O}$ to $\mathrm{N}_{2}$. Functional gene expression of nosZ was affected largely than the bacterial community composition by variations in operating parameters of internal recycle rate.

\section{Acknowledgments}

This research was financially supported by the National Natural Science Foundation of China (No. 51408199), and Basic Scientific and Technological Frontier Project of Henan Province, PR China (Grant No. 142300410313).

\section{References}

[1] IPCC, Climate Change 2007: Synthesis Report, IPCC, Geneva, 2007.

[2] M.J. Kampschreur, H. Temmink, R. Kleerebezem, M. Jetten, M. van Loosdrecht, Nitrous oxide emission during wastewater treatment, Water Res. 43 (2009) 4093-4103.

[3] B.B. Colliver, T. Stephenson, Production of nitrogen oxide and dinitrogen oxide by autotrophic nitrifiers, Biotechnol. Adv. 18 (2000) 219-232.

[4] D.M. Kool, N. Wrage, S. Zechmeister-Boltenstern, M. Pfeffer, D. Brus, O. Oenema, J.W. Van Groenigen, Nitrifier denitrification can be a source of $\mathrm{N}_{2} \mathrm{O}$ from soil: a revised approach to the dual-isotope labelling method, Eur. J. Soil Sci. 61 (2010) 759-772.

[5] J. Wu, J. Zhang, W. Jia, H. Xie, R.R. Gu, C. Li, B. Gao, Impact of COD/N ratio on nitrous oxide emission from microcosm wetlands and their performance in removing nitrogen from wastewater, Bioresour. Technol. 100 (2009) 2910-2917.

[6] S. Otte, N.G. Grobben, L.A. Robertson, M. Jetten, J.G. Kuenen, Nitrous oxide production by Alcaligenes faecalis under transient and dynamic aerobic and anaerobic conditions, Appl. Environ. Microbiol. 62 (1996) 2421-2426.

[7] Y.C. Chiu, M.S. Chung, BNP test to evaluate the influence of $\mathrm{C} / \mathrm{N}$ ratio on $\mathrm{N}_{2} \mathrm{O}$ production in biological denitrification, Water Sci. Technol. 42 (2000) 23-27.

[8] J. Gabarro, P. Gonzalez-Carcamo, M. Ruscalleda, R. Ganigue, F. Gich, M.D. Balaguer, J. Colprim, Anoxic phases are the main $\mathrm{N}_{2} \mathrm{O}$ contributor in partial nitritation reactors treating high nitrogen loads with alternate aeration, Bioresour. Technol. 163 (2014) 92-99.

[9] Z. Hu, J. Zhang, H. Xie, S. Li, J. Wang, T. Zhang, Effect of anoxic/aerobic phase fraction on $\mathrm{N}_{2} \mathrm{O}$ emission in a sequencing batch reactor under low temperature, Bioresour. Technol. 102 (2011) 5486-5491.

[10] P. Wunderlin, M.F. Lehmann, H. Siegrist, B. Tuzson, A. Joss, L. Emmenegger, J. Mohn, Isotope signatures of $\mathrm{N}_{2} \mathrm{O}$ in a mixed microbial population system: constraints on $\mathrm{N}_{2} \mathrm{O}$ producing pathways in wastewater treatment, Environ. Sci. Technol. 47 (2013) 1339-1348.

[11] G. Tallec, J. Garnier, G. Billen, M. Gousailles, Nitrous oxide emissions from secondary activated sludge in nitrifying conditions of urban wastewater treatment plants: effect of oxygenation level, Water Res. 40 (2006) 2972-2980

[12] G. Tallec, J. Garnier, M. Gousailles, Nitrogen removal in a wastewater treatment plant through biofilters: nitrous oxide emissions during nitrification and denitrification, Bioprocess Biosyst. Eng. 29 (2006) 323-333.

[13] M.J. Kampschreur, W.R.L. van der Star, H.A. Wielders, J.W. Mulder, M.S.M. Jetten, M.C.M. van Loosdrecht, Dynamics of nitric oxide and nitrous oxide emission during full-scale reject water treatment, Water Res. 42 (2008) $812-826$.

[14] M.J. Kampschreur, N. Tan, R. Kleerebezem, C. Picioreanu, M. Jetten, M. Loosdrecht, Effect of dynamic process conditions on nitrogen oxides emission from a nitrifying culture, Environ. Sci. Technol. 42 (2008) 429-435.

[15] H. Itokawa, K. Hanaki, T. Matsuo, Nitrous oxide production in high-loading biological nitrogen removal process under low $\mathrm{COD} / \mathrm{N}$ ratio condition, Water Res. 35 (2001) 657-664

[16] R.V. Schulthess, M. Kuehni, W. Gujer, Release of nitric and nitrous oxides from denitrifying activated sludge, Water Res. 29 (1995) 215-226.

[17] K. Hanaki, Z. Hong, T. Matsuo, Production of nitrous oxide gas during denitrification of wastewater, Water Sci. Technol. 26 (1992) 1027-1036.

[18] R.K. Hynes, R. Knowles, Production of nitrous-oxide by nitrosomonas europaea-effects of acetylene, pH, and oxygen, Can. J. Microbiol. 30 (1984) 1397-1404

[19] B. Schonharting, R. Rehner, J.W. Metzger, K. Krauth, M. Rizzi, Release of nitrous oxide $\left(\mathrm{N}_{2} \mathrm{O}\right)$ from denitrifying activated sludge caused by $\mathrm{H}_{2} \mathrm{~S}$-containing wastewater: quantification and application of a new mathematical model, Water Sci. Technol. 38 (1998) 237-246.

[20] Y.T. Ahn, S.T. Kang, S.R. Chae, J.L. Lim, S.H. Lee, H.S. Shin, Effect of internal recycle rate on the high-strength nitrogen wastewater treatment in the combined UBF/MBR system, Water Sci. Technol. 51 (2005) 241-247.

[21] P. Fongsatitkul, D.G. Wareham, P. Elefsiniotis, P. Charoensuk, Treatment of a slaughterhouse wastewater: effect of internal recycle rate on chemical oxygen demand, total Kjeldahl nitrogen and total phosphorus removal, Environ. Technol. 33 (2011) 1755-1759.

[22] P. Czepiel, P. Crill, R. Harriss, Nitrous oxide emissions from municipal wastewater treatment, Environ. Sci. Technol. 29 (1995) 2352-2356.

[23] Y. Kimochi, Y. Inamori, M. Mizuochi, K. Xu, M. Matsumura, Nitrogen removal and $\mathrm{N}_{2} \mathrm{O}$ emission in a full-scale domestic wastewater treatment plant with intermittent aeration, J. Ferment. Bioeng. 86 (1998) 202-206.

[24] CEPB, Standard Methods for Examination of Water and Wastewater (2002), 4th ed., China Environmental Science Press, Beijing, 2004.

[25] W.G. Zumft, K. Frunzke, Discrimination of ascorbate-dependent nonenzymatic and enzymatic, membrane-bound reduction of nitric oxide in denitrifying Pseudomonas perfectomarinus, Biochim. Biophys. Acta 681 (1982) 459-468.

[26] K. Chon, J.S. Chang, E. Lee, J. Lee, J. Ryu, J. Cho, Abundance of denitrifying genes coding for nitrate (narG), nitrite (nirS), and nitrous oxide (nosZ) reductases in estuarine versus wastewater effluent-fed constructed wetlands, Ecol. Eng. 37 (2011) 64-69.

[27] J.A. Baeza, D. Gabriel, J. Lafuente, Effect of internal recycle on the nitrogen removal efficiency of an anaerobic/anoxic/oxic $\left(\mathrm{A}^{2} / \mathrm{O}\right)$ wastewater treatment plant (WWTP), Process Biochem. 39 (2004) 1615-1624.

[28] Z. Hu, J. Zhang, H. Xie, S. Liang, S. Li, Minimization of nitrous oxide emission from anoxic-oxic biological nitrogen removal process: effect of influent $\mathrm{COD} / \mathrm{NH}_{4}{ }^{+}$ratio and feeding strategy, J. Biosci. Bioeng. 115 (2013) 272-278.

[29] J.H. Ahn, S. Kim, H. Park, B. Rahm, K. Pagilla, K. Chandran, $\mathrm{N}_{2} \mathrm{O}$ emissions from activated sludge processes, 2008-2009: results of a national monitoring survey in the United States, Environ. Sci. Technol. 44 (2010) 4505-4511.

[30] S. Toyoda, Y. Suzuki, S. Hattori, K. Yamada, A. Fujii, N. Yoshida, R. Kouno, K. Murayama, H. Shiomi, Isotopomer analysis of production and consumption mechanisms of $\mathrm{N}_{2} \mathrm{O}$ and $\mathrm{CH}_{4}$ in an advanced wastewater treatment system, Environ. Sci. Technol. 45 (2011) 917-922.

[31] P. Wunderlin, J. Mohn, A. Joss, L. Emmenegger, H. Siegrist, Mechanisms of $\mathrm{N}_{2} \mathrm{O}$ production in biological wastewater treatment under nitrifying and denitrifying conditions, Water Res. 46 (2012) 1027-1037.

[32] J.M. Garrido, J. Moreno, R. Mendez-Pampin, J.M. Lema, Nitrous oxide production under toxic conditions in a denitrifying anoxic filter, Water Res. 32 (1998) 2550-2552.

[33] W.G.J.M. Benthum, Nitrogen removal in intermittently aerated biofilm airlift reactor, J. Environ. Eng. 124 (1998) 239-248.

[34] X.Y. Zhu, Y.G. Chen, Reduction of $\mathrm{N}_{2} \mathrm{O}$ and NO generation in anaerobic-aerobic (low dissolved oxygen) biological wastewater treatment process by using sludge alkaline fermentation liquid, Environ. Sci. Technol. 45 (2011) 2137-2143

[35] H. Lu, K. Chandran, D. Stensel, Microbial ecology of denitrification in biological wastewater treatment, Water Res. 64 (2014) 237-254.

[36] H. Lu, K. Chandran, Factors promoting emissions of nitrous oxide and nitric oxide from denitrifying sequencing batch reactors operated with methanol and ethanol as electron donors, Biotechnol. Bioeng. 106 (2010) 390-398.

[37] J. Desloover, S.E. Vlaeminck, P. Clauwaert, W. Verstraete, N. Boon, Strategies to mitigate $\mathrm{N}_{2} \mathrm{O}$ emissions from biological nitrogen removal systems, Curr. Opin. Biotechnol. 23 (2012) 474-482. 